\title{
KEMAMPUAN DISPOSISI BERPIKIR KRITIS SISWA YANG BERKATEGORI RENDAH DALAM MEMECAHKAN MASALAH PERSAMAAN NILAI MUTLAK LINIER SATU VARIABEL
}

\author{
Siti Na'imatul Uyun ${ }^{1}$, Fuat ${ }^{2}$ \\ ${ }^{1,2}$ Program Studi Pendidikan Matematika, Fakultas Pedagogi dan Psikologi, \\ Universitas PGRI Wiranegara Pasuruan \\ Email: ${ }^{1}$ naimatuluyun54@gmail.com
}

\begin{abstract}
ABSTRAK
Disposisi berpikir kritis merupakan sikap selalu menggunakan pemikiran kritis sebelum melaksanakan tindakan. Penelitian ini merupakan penelitian kualitatif yang bertujuan untuk mendeskripsikan disposisi berpikir kritis siswa yang berkategori rendah dalam memecahkan masalah persamaan nilai mutlak linier satu variabel. Subjek dalam penelitian ini yaitu siswa kelas X MIPA-3 SMA Negeri Gondangwetan Kabupaten Pasuruan tahun pelajaran 2019/2020 dengan instrumen berupa tes dan wawancara. Hasil penelitian ini menunjukkan bahwa salah satu siswa dalam memecahkan masalah persamaan nilai mutlak linier satu variabel berpotensi memiliki disposisi berpikir kritis yang berkategori rendah. Hal ini ditunjukkan dengan salah satu siswa yang mampu menyampaikan beberapa pendapat dan bertanya mengenai kesalahan pada soal yang diberikan. Hasil pekerjaan dari siswa ini berpotensi memenuhi 2 indikator dari 7 indikator disposisi berpikir kritis, yaitu truth-seeking dan inquisitiveness. Selain itu, siswa mampu memenuhi ciri - ciri khusus seseorang dikatakan memiliki disposisi berpikir kritis ketika dihadapkan pada permasalahan dan pertanyaan. Rata - rata siswa yang belum memiliki disposisi berpikir kritis pada dirinya ditandai dengan: kurangnya kesiapan siswa dalam menghadapi masalah maupun sikap siswa yang kurang kritis mengenai permasalahan yang diberikan, siswa kurang cermat dan teliti, siswa langsung mengerjakan tanpa menganalisis terlebih dahulu soal yang telah diberikan dan siswa beranggapan bahwa soal yang telah diberikan selalu benar.
\end{abstract}

Kata Kunci: Disposisi Berpikir Kritis, Pemecahan Masalah, Disposisi Rendah

\begin{abstract}
Critical thinking disposition is an attitude of always using critical thinking before carrying out actions. This research is a qualitative study aimed at describing the critical thinking disposition of students who are low-category in solving the problem of absolute linear values of a single variable. The subject in this study is class X MIPA-3 SMA Negeri Gondangwetan Pasuruan District Year lesson 2019/2020 with instrument in the form of tests and interviews. The results of this study showed that one of the students in solving the problem of absolute linear value equations of a single variable has the potential to have a critical thought disposition which is low-category. This is demonstrated by one of the students who are able to convey some opinions and ask questions about the mistakes on the given question. The work of this student has the potential to meet 2 indicators of 7 critical thinking disposition indicators, namely truth-seeking and inquisitiveness. In addition, students are able to fulfill the special characteristics of a person said to have a critical thinking disposition when faced with problems and questions. The average of students who have not had a critical thinking disposition on him are characterized by: lack of readiness of students in the face of problems and attitudes of students who are less critical about the problems given, students are less careful and thorough, students immediately work without analyzing the questions that have been given and students think that the problem that has been given is always true.
\end{abstract}


Keywords: Critical thinking disposition, problem solving, low dispositions

\section{PENDAHULUAN}

Pembelajaran matematika bertujuan agar siswa berpikir kritis untuk menyelesaikan masalah yang diajukan. Seseorang yang berpikir kritis cenderung menganalisis terlebih dahulu segala informasi yang datang kepadanya (argument, bukti, atau hanya klaim) dengan cermat, dan menggunakan penalaran yang baik. Pemikir yang kritis tidak akan menelan mentah - mentah semua informasi atau bahkan perintah yang diajukan kepadanya tanpa harus melakukan refleksi terlebih dahulu (As'ari dkk., 2019).

Dalam kehidupan akademis, berpikir kritis dipandang memiliki potensi untuk membantu tumbuh kembangnya kecerdasan siswa (Alghadari, 2013). Ketika siswa berusaha memecahkan masalah, dibutuhkan kegigihan dalam menghadapi dan menyelesaikan masalah dengan gairah dan perhatian yang serius, tekun dalam mengerjakannya, rasa ingin tahu dan percaya diri. Semua kebutuhan dalam usaha memecahkan masalah merupakan indikator disposisi matematik yang dikemukakan Polking (Alghadari, 2013). Dengan demikian, pentingnya menggunakan disposisi matematik sekaligus disposisi berpikir kritis merupakan keutamaan dalam kehidupan sehari - hari untuk memecahkan masalah hal ini dikemukakan oleh Saurino (Alghadari, 2013).

Menurut Ennis (As'ari dkk., 2019), berpikir kritis yaitu pemikiran reflektif yang difokuskan untuk mengambil keputusan tentang apa yang harus dipercaya atau apa yang harus dilakukan. Berpikir kritis dibagi menjadi dua komponen, yaitu keterampilan berpikir kritis dan disposisi berpikir kritis. Keterampilan berpikir kritis merupakan aspek - aspek intelektual dalam berpikir kritis, sedangkan disposisi berpikir kritis merupakan kecenderungan untuk selalu menggunakan sikap untuk berpikir kritis hal ini dikemukakan Facione (Lai, 2011). Hal ini didukung oleh Halpern (Yunarti, 2011) yang mengatakan bahwa seorang pemikir kritis yang ideal harus memiliki kemampuan dan disposisi berpikir kritis. Dalam kasus ini berpikir kritis yang dihadapi oleh siswa masuk dalam kategori disposisi.

Menurut Katz (Mahmudi, 2011), disposisi adalah kecenderungan untuk berperilaku secara sadar (consciously), teratur (frequently), dan sukarela (voluntary) yang mengarah pada pencapaian tujuan tertentu. Perilaku-perilaku tersebut antara lain: percaya diri, gigih, ingin tahu, dan berpikir fleksibel. Sementara itu Solomon (Herlina, 2013), mendefinisikan disposisi sebagai sekumpulan sikap-sikap pilihan dengan kemapuan yang memungkinkan sikap-sikap pilihan tadi muncul dengan cara tertentu. Menurut Ennis (Zhang, 2017), disposisi adalah bagian penting dalam berpikir kritis karena jika seseorang yang mampu berpikir secara kritis tetapi tidak mau menggunakan kemampuan berpikir, dengan demikian tidak dianggap sebagai pemikir kritis. Berdasarkan pendapat beberapa ahli tersebut, dapat disimpulkan bahwa disposisi adalah kecendrungan atau kebiasaan untuk berpikir dalam cara/kondisi tertentu sebelum melakukan sesuatu.

Disposisi berpikir kritis merupakan sebuah kecenderungan dalam kondisi tertentu untuk melakukan sesuatu (Sholihah dan Shanti, 2017). Kemudian (Facione dan Giancarlo, 2006) mengatakan bahwa "critical thinking dispositions as a person's internal motivation to think critically whwn faced with problems to solve, ideas to evaluate, or decisions to make", yang berarti bahwa seseorang ketika menghadapi suatu masalah, mengevaluasi suatu ide, atau membuat keputusan akan berpikir kritis untuk memecahan suatu masalah tersebut, mengevaluasi suatu ide, atau membuat keputusan. Berpikir kritis dalam hal ini sebagai suatu motivasi internal yang biasa disebut dengan disposisi berpikir kritis. Berdasarkan definisi di atas, dapat disimpulkan bahwa disposisi berpikir kritis adalah sebuah kecenderungan untuk bersikap selalu menggunakan pemikiran kritis sebelum melaksanakan tindakan. Disposisi berpikir kritis menggambarkan semangat kekritisan atau kecenderungan untuk berpikir kritis 
dengan karakteristik keingintahuan mendalam, ketajaman pemikiran, ketekunan mengembangkan akal, kebutuhan atas informasi yang dapat dipercaya. Orang yang mempunyai disposisi berpikir kritis cenderungan memikirkan terlebih dahulu segala sesuatu yang ada kaitanya dengan tindakan yang akan dilakukan dan tidak mau menerima sesuatu yang diberikan secara membabi buta. Disposisi berpikir kritis adalah gerbang untuk kegiatan berpikir kritis dan sebagai tahapan awal yang digunakan individu untuk mencapai kegiatan berpikir kritis (Hunaepi dkk., 2018).

Menurut Facione (As'ari dkk., 2019), seseorang dikatakan memiliki disposisi berpikir kritis ketika dihadapkan pada permasalahan dan pertanyaan jika memiliki ciri-ciri khusus, yaitu (a) mengklarifikasi tentang kejelasan dari sebuah masalah, (b) mencari sumber yang relevan, (c) rasional dalam menerapkan kriteria, (d) mengerjakan masalah yang kompleks dan terurut, (e) fokus dalam memperhatikan masalah utama, (f) tekun meskipun menemui kesulitan, (g) teliti dengan mempertimbangkan subjek dan keadaan.

Menurut Facione \& Facione (As'ari dkk., 2019), terdapat 7 skala pada instrument CCTDI (California Critical Thinking Disposition Inventory) yang digunakan untuk menentukan disposisi berpikir kritis seseorang, diantaranya: (1) Truth-seeking, kebiasaan selalu meng-inginkan pemahaman terbaik tentang situasi, disertai alasan dan bukti yang terkait; (2) Open-mindedness, kecenderungan untuk membiarkan orang lain menyuarakan pandangannya, orang yang berpikiran terbuka memiliki sikap toleransi dan penerimaan terhadap pendapat orang lain; (3) Analyticity, kecenderungan untuk berhati-hati terhadap apa yang terjadi berikutnya. Hal ini berkaitan dengan antisipasi konsekuensi baik atau buruknya situasi, pilihan, proposal dan rencana; (4) Systematicity, kecenderungan atau kebiasaan kerja keras untuk menyelesaikan masalah dengan disiplin dan sistematis; (5) Self-confidence, kecenderungan memercayai penggunaan akal dan berpikir reflektif untuk memecahkan masalah; (6) Inquisitiveness, keingintahuan intelektual, yaitu kecenderungan untuk ingin tahu segala sesuatu, bahkan pada hal secara jelas tidak berguna saat ini; (7) Maturity of judgement, kematangan kognitif yang berkaitan dengan kecenderungan untuk melihat masalah yang rumit, membuat penilaian secara tepat waktu, dan tidak melakukan penundaan pada apa yang bisa dilakukannya.

Pentingnya peran disposisi dalam menunjang kemampuan berpikir kritis siswa tidak terlalu banyak yang memperhatikan. Kurangnya perhatian terhadap disposisi berpikir kritis siswa adalah ketika guru hanya memperhatikan hasil pekerjaan dan nilai ulangan siswa, tanpa memperdulikan sikap siswa dalam pencarian kebenaran, rasa ingin tahu, dan berpikir terbuka selama proses pembelajaran berlangsung. Pada dasarnya, kemampuan disposisi berpikir kritis adalah kemampuan esensial yang perlu dimiliki dan dikembangkan oleh siswa yang belajar matematika. Namun pada kenyataanya kemampuan disposisi berpikir kritis siswa masih cukup rendah, karena selama proses pembelajaran di kelas masih sedikit siswa yang mempunyai kemampuan disposisi berpikir kritis.

Dalam proses pembelajaran, siswa diharapkan mampu menerapan kompetensi suatu mata pelajaran yang telah disajikan dan dipelajari secara konstruktivis. Hal ini dikarenakan "Konstruktivisme memandang siswa secara konstan memeriksa informasi baru terhadap aturan - aturan lama dan merevisi aturan-aturan bila mereka bekerja dalam waktu relatif singkat" (Fuat, 2014). Indikator - indikator disposisi berpikir kritis dalam penelitian ini diukur dengan menggunakan masalah pada materi persamaan nilai mutlak linier satu variabel.

Dalam penelitian ini merujuk pada indikator disposisi berpikir kritis menurut Facione \& Facione, sehingga dapat di tarik kesimpulan bahwa siswa yang berpotensi memiliki kemampuan disposisi berpikir kritis yang berkategori tinggi apabila mampu memenuhi 6 dari 7 indikator disposisi berpikir kritis, siswa berkemampuan disposisi berpikir kritis yang berkategori sedang apabila mampu memenuhi 4 dari 7 indikator disposisi berpikir kritis dan 
siswa berkemampuan disposisi berpikir kritis yang berkategori sedang apabila mampu memenuhi 2 dari 7 indikator disposisi berpikir kritis

Berdasarkan latar belakang di atas, maka rumusan masalah pada penelitian ini adalah "Bagaimana kemampuan disposisi berpikir kritis siswa yang berkategori rendah dalam memecahkan masalah persamaan nilai mutlak linier satu variabel ?".

Berdasarkan rumusan masalah di atas, tujuan yang ingin dicapai dalam penelitian ini adalah menganalisis kemampuan disposisi berpikir kritis siswa yang berkategori rendah dalam memecahkan masalah persamaan nilai mutlak linier satu variabel.

\section{METODE}

Penelitian ini dilaksanakan di SMA Negeri 1 Gondangwetan Kabupaten Pasuruan tahun pelajaran 2019/2020 pada mata pelajaran matematika. Subjek dalam penelitian ini adalah siswa kelas X MIPA-3 yang terdiri dari 30 siswa. Pendekatan dalam penelitian ini merupakan pendekatan kualitatif dengan jenis penelitian deskriptif. Menurut Creswell dan Clark (dalam Lestari \& Yudhanegara, 2017) penelitian deskriptif merupakan metode untuk menganalisis dan menyajikan data berdasarkan fakta secara sistematis, serta data dalam penelitian ini berasal dari tugas setelah proses pembelajaran berlangsung pada tanggal 27 Agustus 2019 pada jam pelajaran jam ke 5-6 atau pada pukul 10.25 - 11.45. Materi yang disajikan pada pertemuan itu mengenai bentuk umum dan cara penyelesaian persamaan nilai mutlak linier satu variabel. Referensi yang digunakan saat kegiatan pembelajaran yaitu UKBM dan buku paket matematika kelas x kurikulum 2013 revisi 2016.Sebelum dimulai pemberian tugas terlebih dahulu dilakukan kegiatan pembelajaran dengan menggunakan model Direct instruction (DI). Kegiatan pembelajaran dilakukan selama 80 menit. Setelah selesai pembelajaran siswa diberikan tugas yang diberikan terdapat kesalahan/kontradiksi dengan tingkat soal sedang yang dikerjakan secara individu.

Adapun kriteria dalam pengambilan subjek yaitu siswa yang mampu melakukan proses pengecekan kebenaran informasi yang ada di soal sebelum menyelesaikan soal, menyatakan/menuliskan bahwa soal yang diberikan memiliki informasi yang salah/kontradiksi serta mampu mempertahankan pendapatnya mengenai adanya kesalahan dari soal yang diberikan, mampu memberikan bukti yang sesuai dengan konsep matematika yang seharusnya. Dengan demikian dalam penelitian ini menggunakan teknik purposive sampling yaitu dipilih dengan pertimbangan dan tujuan tertentu untuk mendapatkan siswa yang memiliki disposisi berpikir kritis untuk menentukan subjek. Artinya, tidak semua siswa dari kelas yang dipilih untuk dijadikan penelitian, hanya beberapa siswa memiliki kriteria yang sudah dijelaskan tersebut untuk dijadikan subjek penelitian. Teknik purposive sampling ini dilakukan dengan pemberian tugas individu kepada seluruh siswa kelas X MIPA-3 SMA Negeri 1 Gondangwetan. Adapun diagram 1 tentang pemilihan subjek dalam penelitian ini adalah sebagai berikut: 


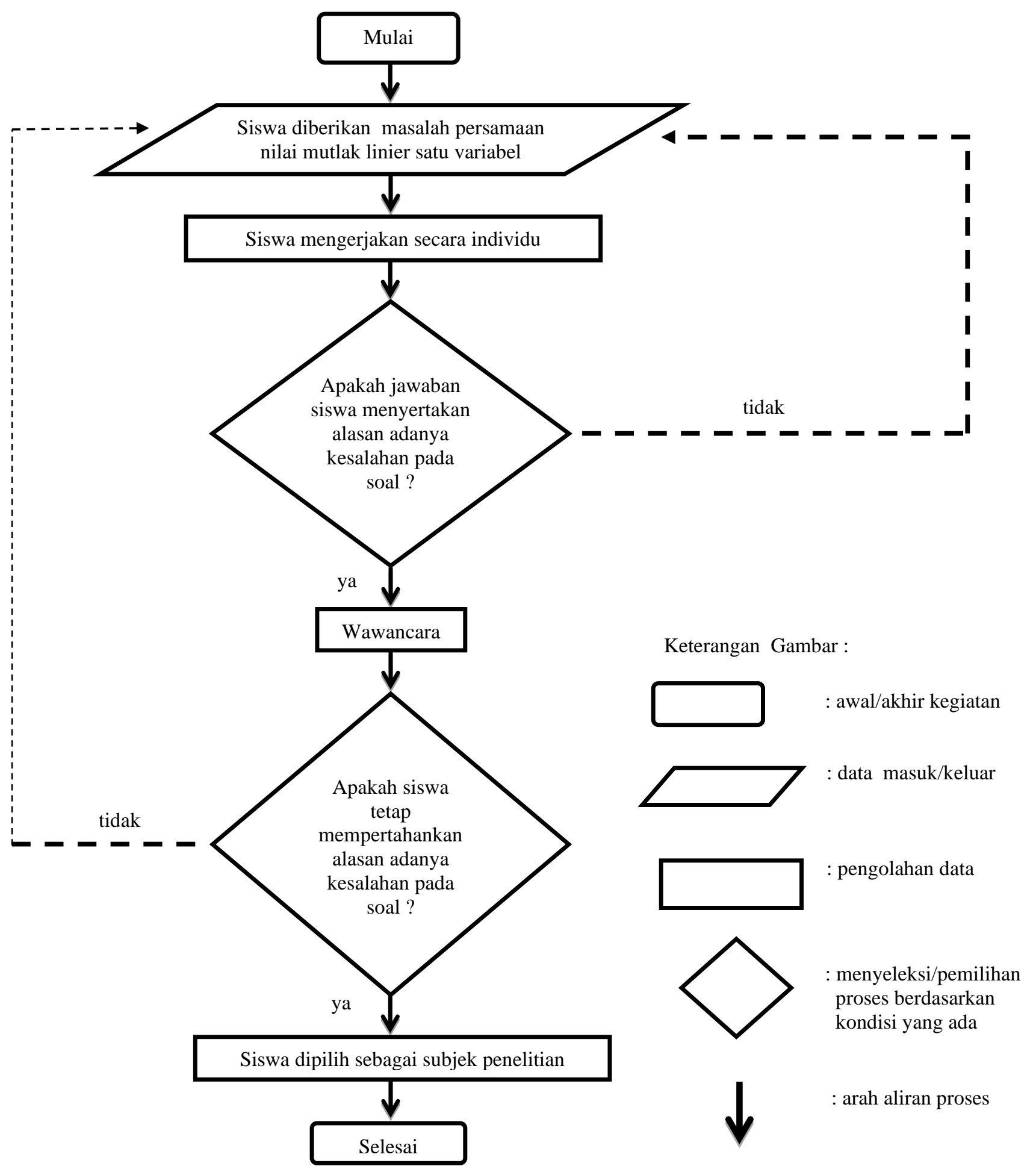

Diagram 1 Alur Pemilihan Subjek Penelitian

\section{HASIL}

Setelah siswa mengikuti kegiatan pembelajaran dengan siswa diberikan tugas dengan permasalahan terkait persamaan nilai mutlak linier satu variabel yang diikuti oleh 30 siswa. Didalam tugas siswa diberikan soal yang terdapat kesalahan/kontradiksi dengan tingkat soal sedang yang dikerjakan secara individu. dengan tingkat kesulitan sedang. Hal ini untuk mengetahui pencapaian indikator - indikator berpikir kritis siswa. Berikut ini adalah soal yang diberikan: 


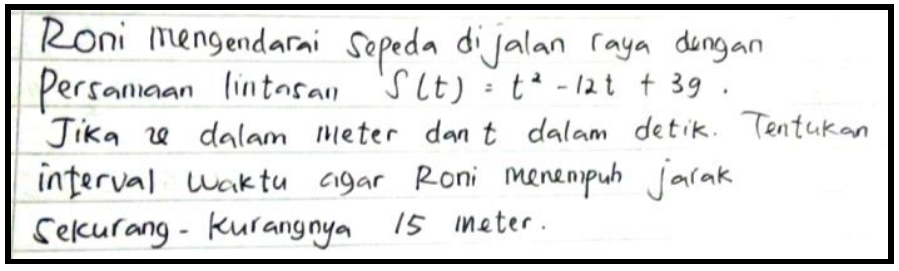

Gambar 1. Soal Tugas Asli

Pada soal terdapat kesalahan mengenai variable $x$ disini tidak menggambarkan jarak melainkan variabel $S(t)$ yang sebenarnya menggambarkan jarak yang dimaksud dalam soal tersebut.

Variabel pengecoh

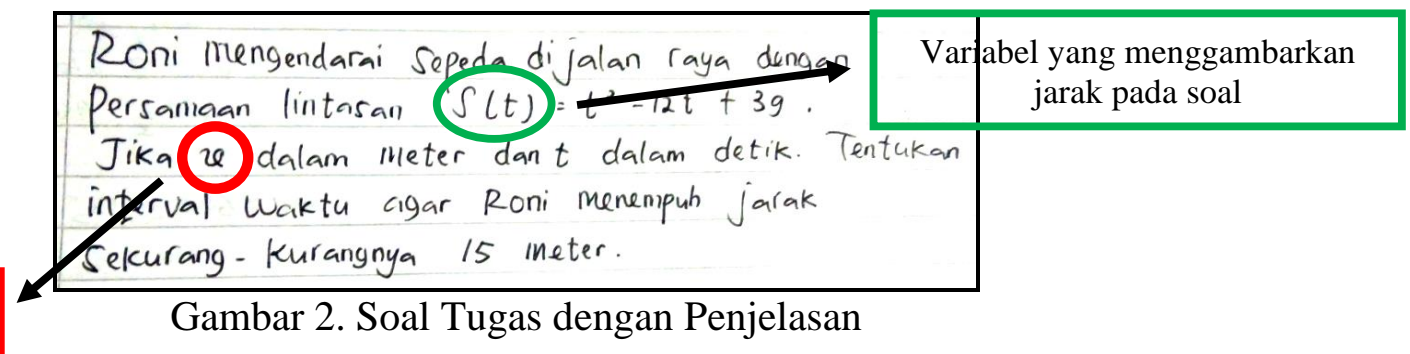

Untuk mengerjakan tugas, siswa diberikan waktu selama 5 hari dengan ketentuan diperbolehkan melihat referensi baik buku tulis, UKBM, dan buku paket,internet, dan lain lain. Tugas dikumpulkan dimeja guru ketika pembelajaran di kelas. Untuk mendapatkan subjek penelitian dilakukan pengoreksian dan menelaah jawaban siswa satu persatu untuk mengetahui proses berpikir siswa dalam menyelesaikan soal yang nantinya akan dibagikan kembali ke siswa. Setelah tugas diberikan, ada salah satu siswa yang bertanya mengenai adanya ke anehan dari variabel - variabel yang terdapat di permasalahan soal tugas yang telah di berikan. Dan setelah di koreksi dan ditelaah hasil jawaban siswa, peneliti menemukan ada jawaban siswa benar meskipun permasalah yang diberikan mengandung unsur kesalahan, yang nantinya akan diidentifikasi dan ditelusuri lebih lanjut tentang kemampuan disposisi berpikir kritis siswa. Untuk mengetahui lebih jelas lagi tentang disposisi berpikir kritis siswa maka peneliti akan mewawancarai subjek.

Berikut ini adalah jawaban dari subjek:

Siswa

menggambarkan

variabel $\mathrm{S}(\mathrm{t})$

dengan benar

meskipun pada

soal asli variabel

$x$ yang

sebenarnya

menggambarkan
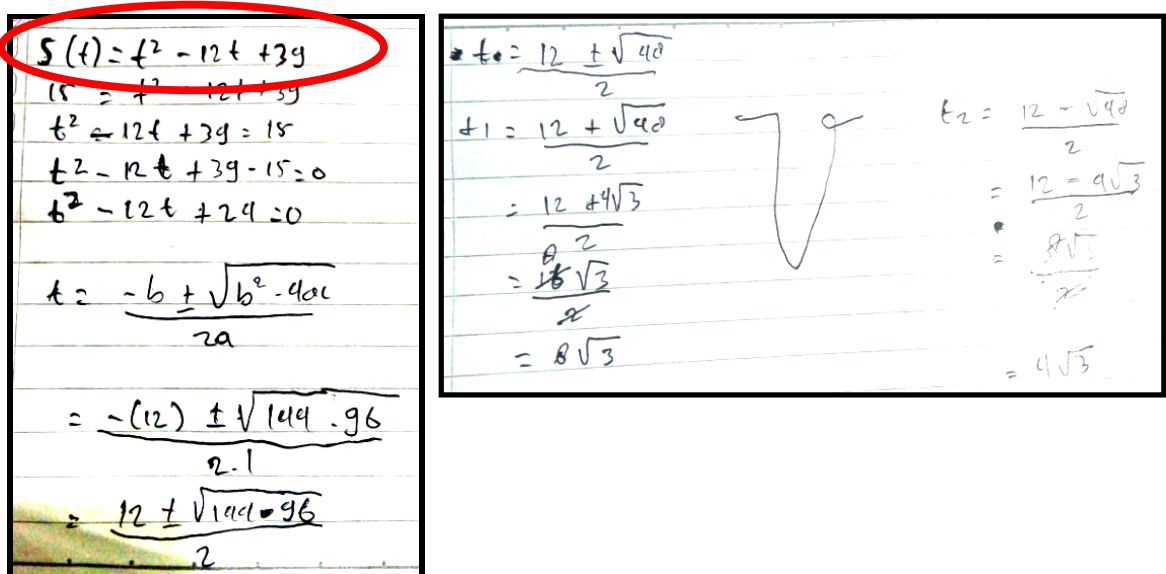

Gambar 3. Jawaban Subjek 
Setelah memperhatikan jawaban dari subjek, dapat dilihat bahwa pada jawaban ini subjek mampu mengerjkan soal dengan benar meskipun pada soal sebenarnya terdapat kesalahan. Subjek mampu menunjukkan bahwa variabel $S(t)$ yang merupakan persamaan lintasan menggambarkan jarak yang dimaksud dalam soal tersebut. Namun sebelum mengerjakan soal yang telah diberikan, subjek ini bertanya mengenai variabel - variabel yang diketahui dalam soal tersebut. Berikut hasil wawancara dengan subjek:

Tabel 1. Hasil Wawancara 1

\begin{tabular}{|c|c|}
\hline Wawancara & Penjelasan \\
\hline $\begin{array}{l}\mathrm{S}: \text { "Variabel } x \text { yang dimaksud dalam soal itu } \\
\text { tidak salahkah bu?" }\end{array}$ & $\begin{array}{l}\text { Siswa bertanya mengenai variabel - } \\
\text { variabel dalam permasalah yang } \\
\text { diberikan. Hal ini menunjukkan salah } \\
\text { satu indikator berpikir kritis yaitu rasa } \\
\text { ingin tahu }\end{array}$ \\
\hline G : "Maksud salah disini seperti apa?" & Guru mempertegas pertanyaan siswa \\
\hline $\begin{array}{l}\text { S: "Di soal di ketahui bahwa variabel } x \text { dalam } \\
\text { meter sedangkan dalam persamaan lintasan } \\
S(t)=t^{2}-12 t+39 \text { tidak mengadung } \\
\text { variabel } x \text { " }\end{array}$ & $\begin{array}{l}\text { Siswa menjelaskan pendapatnya } \\
\text { mengenai adanya keanehan dalam soal. } \\
\text { Hal ini menunjukkan salah satuindikator } \\
\text { berpikir kritis yaitu pencarian kebenaran }\end{array}$ \\
\hline $\begin{array}{l}\mathrm{G}: \text { "Variabel } x \text { pada soal itu menggambarkan } \\
\text { jarak bukan persamaaan lintasan" }\end{array}$ & $\begin{array}{l}\text { Guru memberikan jawaban dan } \\
\text { mengecek apakah siswa masih mampu } \\
\text { mempertahankan pendapatnya atau } \\
\text { malah terkecoh dengan jawaban yang } \\
\text { telah di sampaikan guru. }\end{array}$ \\
\hline $\begin{array}{l}\text { S: "Iya bu, tetapi pada soal tidak terdapat } \\
\text { variabel } x \text { dalam meter dan variabel } t \text { dalam } \\
\text { detik" }\end{array}$ & $\begin{array}{l}\text { Siswa mempertegas } \\
\text { mempertahankan pendapatnya bahwa } \\
\text { penadapatnya itu benar. Hal ini } \\
\text { menunjukkan salah satu indikator } \\
\text { berpikir kritis yaitu pencarian kebenaran }\end{array}$ \\
\hline $\begin{array}{l}\text { G: "Iya, variabel } x \text { pada soal itu } \\
\text { menggambarkan jarak yang ditempuh dan } \\
\text { variabel } t \text { itu menggambarkan interval } \\
\text { waktu yang dibutuhkan" }\end{array}$ & Guru memberikan penjelasan \\
\hline
\end{tabular}

Berdasarkan kutipan wawancara diatas didapatkan bahwa siswa ini berpotensi mampu mencapai indikator inquisitiveness yang ditunjukkan melalui pertanyaan - pertanyaan yang siswa ini tanyakan mengenai kesalahan dari soal yang diberikan. Siswa ini juga berpotensi mampu mencapai indikator truth-seeking yang ditunjukkan melalui penyampaian beberapa pendapat mengenai variabel- variabel yang terdapat dalam soal yang diberikan. Menurutnya variabel- variabel yang terdapat dalam soal tidak sama dengan apa yang siswa ini ketahui dari soal yang telah diberikan.

Hasil penelitian ini menunjukkan bahwa salah satu siswa berpotensi memiliki kemampuan disposisi berpikir kritis terhadap masalah yang diberikan. Hal ini didukung oleh Bestari (2018) mengajukan konsep disposisi berpikir kritis yang disebut konsep berpikir kritis triadic disposition. Konsep tersebut terdiri dari tiga hal, yaitu kepekaan, kecenderungan, dan kemampuan.

Berdasarkan hasil tugas dan kutipan wawancara di atas didapatkan bahwa siswa tersebut mampu mengutarakan pendapatnya mengenai adanya kontradiksi/kesalahan pada soal yang diberikan dan tetap mengerjakan soal dengan memberikan bukti yang sesuai untuk menyelesaikan soal berdasarkan konsep matematika yang seharusnya. Setelah peneliti 
melakukan wawancara dan mengamati hasil tugas siswa tersebut, maka siswa ini diambil sebagai subjek penelitian.

Untuk membuktikan subjek ini memiliki kemampuan disposisi berpikir kritis dalam sirinya, maka subjek diberikan permasalahan kedua berupa soal yang sama dengan soal awal namun ada beberapa point yang dikurangi tetapi tidak merubah soal awal. Waktu pemberian permasalahan kedua ini satu minggu setalah pengkoreksian jawaban soal tugas awal yaitu sekitar 1 minggu dengan waktu pengerjakan selama 1 hari. Untuk pengerjaan soal pada permasalahan kedua ini subjek diperbolehkan melihat referensi baik buku tulis, UKBM, buku paket, internet, dan lain - lain. Tugas dikumpulkan dimeja guru ketika pembelajaran di kelas. Berikut ini adalah permasalahan kedua yang diberikan:

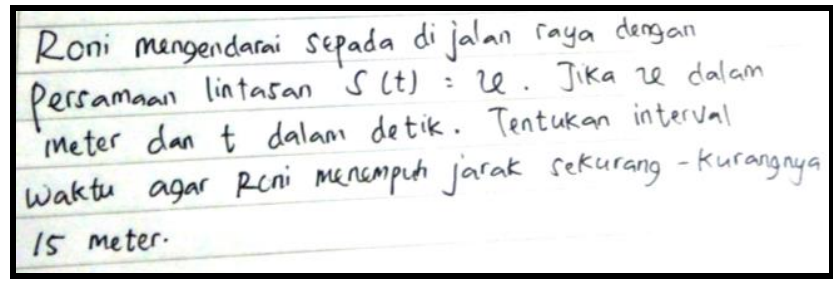

Gambar 4. Soal Tugas Kedua

Tabel 2. Perbedaan Soal Pertama dan Kedua

Soal Tugas 1
\begin{tabular}{l|}
\hline Roni mengendarai sepeda dijalan raya dengan \\
Persamaan lintasan $S(t)=t^{2}-12 t+39$. \\
Jika $u$ dalam ineter dan $t$ dalam detik. Tentukan \\
interval waktu agar Roni menempuh jaiak \\
Sekurang - kurangnya 15 ineter.
\end{tabular}

Pada soal pertama variabel $S(t)$ diketahui dan merupakan persamaan lintasan menggambarkan jarak yang dimaksud dalam soal tersebut.

\section{Soal Tugas 2}

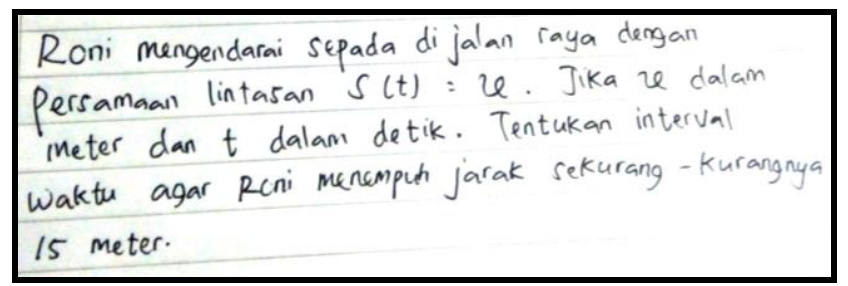

Pada soal kedua variabel $S(t)$ tidak diketahui dan nilai $S(t)=x$, dengan nilai $x$ disini masih belum diketahui juga.

Setelah tugas diberikan, subek ini langsung bertanya mengenai permasalahan yang diberikan pada tugas tersebut, ia masih ingat dengan permasalahn awal yang telah diberikan pada soal tugas 1 dan ia mampu menjelaskan adanya variabel yang di kurangi. Untuk mempertegas pernyataan subjek, maka peneliti mewawancarai subjek. Berikut hasil wawancara dengan subjek. 
Tabel 3. Hasil Wawancara 2

\begin{tabular}{l|l}
\hline \multicolumn{1}{c|}{ Wawancara } & \multicolumn{1}{c}{ Penjelasan } \\
S : "Itu soal tugas yang minggu kemarin & $\begin{array}{l}\text { Siswa bertanya mengenai persamaan soal } \\
\text { yang diberikan dengan soal pertama. Hal } \\
\text { ini menunjukkan salah satu indikator } \\
\text { berpikir kritis yaitu rasa ingin tahu }\end{array}$ \\
\hline G : "Ohhh iya, apakah benar itu soal minggu & Guru mempertegas pertanyaan siswa \\
lalu?" & Siswa menjelaskan pendapatnya \\
\hline S : "Iya bu" & Guru mempertegas pertanyaan siswa \\
\hline G : "Masih ingat?" & $\begin{array}{l}\text { Siswa menjelaskan pendapatnya mengenai } \\
\text { adanya keanehan dalam soal. }\end{array}$ \\
\hline G : "Masih bu,tetapi ada yang aneh dari soal \\
itu bu ?" & Guru mempertegas pertanyaan siswa \\
\hline S : "Soalnya ada berbeda bu, di persamaan & $\begin{array}{l}\text { Siswa menjelaskan pendapatnya. Hal ini } \\
\text { menunjukkan salah satu indikator berpikir } \\
\text { kritis yaitu pencarian kebenaran }\end{array}$ \\
\hline G : "Bagaimana cara penyelesaian jika & $\begin{array}{l}\text { Guru bertanya cara penyelesaian soal } \\
\text { seperti yang diberikan. }\end{array}$ \\
\hline Soalnya seperti itu ?" & $\begin{array}{l}\text { Siswa menjelaskan pendapatnya. Hal ini } \\
\text { menunjukkan salah satu indikator berpikir } \\
\text { dikerjakan karena nilai persamaannya } \\
\text { tidak ada atau tidak diketahui." }\end{array}$ \\
\hline
\end{tabular}

Dari hasil wawancara dan pemberian permasalahan kedua, subjek mampu menunjukkan dan menjelaskan adanya pengurangan variabel - variabel pada permasalahan yang diberikan. Hal ini menunjukkan bahwa subjek berpotensi mempunyai kemampuan disposisi berpikir kritis dalam menyelesaikan masalah matematika pada materi persamaan nilai mutlak linier satu variabel.

\section{PEMBAHASAN}

Berdasarkan hasil penelitian ini menunjukkan bahwa subjek dalam memecahkan masalah persamaan nilai mutlak linier satu variabel berpotensi memiliki kemampuan disposisi berpikir kritis yang berkategori rendah. Hal ini ditunjukkan dengan subjek mampu memenuhi 2 indikator dari 7 indikator disposisi berpikir kritis yaitu: (1) truth-seeking yang ditunjukkan melalui penyampaian beberapa pendapat mengenai variabel - variabel yang terdapat dalam permasalahan yang diberikan; 2 inquisitiveness yang ditunjukkan melalui pertanyaan - pertanyaan yang ditanyakan siswa mengenai kejanggalan dari permasalahan yang diberikan. Dikatakan disposisi berpikir kritis yang berkategori rendah, karena bukti yang ditunjukkan oleh subjek masih belum cukup untuk menunjukkan disposisi berpikir krtitis dalam dirinya. Dikarenakan selain terdapat indikator -indikator dalam mengukur disposisi berpikir kritis terdapat pula ciri - ciri khusus seseorang dikatakan memiliki disposisi berpikir kritis ketika dihadapkan pada permasalahan dan pertanyaan, yaitu: (a) mengklarifikasi tentang kejelasan dari sebuah masalah, (b) mencari sumber yang relevan, (c) rasional dalam menerapkan kriteria, (d) mengerjakan masalah yang kompleks dan terurut, (e) fokus dalam memperhatikan masalah utama, (f) tekun meskipun menemui kesulitan, (g) teliti dengan mempertimbangkan subjek dan keadaan. Subjek dalam penelitian ini masih belum bisa mencapai ciri - ciri mencari sumber yang relevan dan rasional dalam menerapkan kriteria. Jadi, disposisi berpikir kritis dalam diri subjek ini masih berkategori rendah.

Hasil penelitian juga menunjukkan bahwa siswa yang berpotensi memiliki kemampuan disposisi berpikir kritis yang berkategori tinggi apabila mampu memenuhi 6 dari 7 indikator 
disposisi berpikir kritis, siswa berkemampuan disposisi berpikir kritis yang berkategori sedang apabila mampu memenuhi 4 dari 7 indikator disposisi berpikir kritis dan siswa berkemampuan disposisi berpikir kritis yang berkategori sedang apabila mampu memenuhi 2 dari 7 indikator disposisi berpikir kritis dan mampu memenuhi ciri - ciri khusus seseorang dikatakan memiliki disposisi berpikir kritis ketika dihadapkan pada permasalahan dan pertanyaan.

Berdasarkan temuan penelitian diatas, juga dapat dilihat bahwa orang yang berdisposisi berpikir kritis ketika dihadapkan pada suatu masalah akan mengecek terlebih dahulu permasalahan yang dihadapi sebelum menyelesaikannya, dengan demikian dapat disimpulkan bahwa indikator yang paling utama dalam mengukur truth-seeking adalah indikator pengecekan kebenaran sebelum menyelesaikan soal. Hal ini sejalan dengan penelitian yang dilakukan oleh Purwanto (2018) yang menjelaskan bahwa proses pencarian kebenaran ketika memecahkan masalah matematika didasarkan pada proses memeriksa kebenaran di balik informasi yang terkait dengan pertanyaan dan koordinasi untuk membuat keputusan tentang pemecahan masalah yang dimediasi oleh semua benda yang bersangkutan. Upaya untuk mengembangkan keterampilan berpikir tingkat tinggi, terutama dalam disposisi berpikir kritis dapat dilakukan dengan memberikan pembelajaran berbasis masalah. Senada dengan hal ini, penelitian yang dilakukan oleh Astawa (2018) menjelaskan bahwa proses siswa dalam membangun pengetahuan ketika menyelesaiakan masalah matematika, siswa melakukan proses pencarian kebenaran dan juga melakukan proses pemahaman masalah, mengeksplorasi, merumuskan, membenarkan, dan membuktikan kemungkinan kesalahan informasi dalam pertanyaan - pertanyaan yang diberikan. Jadi dan begitu, proses siswa dalam membangun pengetahuan dapat digunakan sebagai dasar untuk membuat keputusan untuk melakukan pencarian kebenaran ketika menghadapi masalah matematika dan menyelesaikannya (Moore, 2010). Oleh karena itu, disposisi berpikir kritis harus diterapkan dan dikembangkan dalam proses pembelajaran dalam semua mata pelajaran, khususnya dalam mata pelajaran matematika untuk menghasilkan siswa yang memiliki kualitas pemikiran kritis yang baik.

\section{SIMPULAN DAN SARAN}

Berdasarkan hasil penelitian dan menjawab tujuan penelitian, maka penelitian ini dapat disimpulkan bahwa, salah satu siswa mampu memenuhi 2 dari 7 indikator disposisi berpikir kritis yaitu indikator truth-seeking dan inquisitiveness. Indikator disposisi berpikir kritis tersebut dibuktikan dari sikap siswa yang bertanya dan menyampaikan pendapatnya mengenai permasalahan yang diberikan. Bukan hanya indikator disposisi berpikir kritis yang mampu ditunjukkan, sikap kepekaan dan kecenderungan dalam menghadapi situasi dan kondisi tertentu juga sudah di tunjukkan siswa tersebut. Selain itu, siswa sudah mampu memenuhi ciri - ciri khusus seseorang dikatakan memiliki disposisi berpikir kritis ketika dihadapkan pada permasalahan dan pertanyaan yaitu: mengklarifikasi tentang kejelasan dari sebuah masalah, mengerjakan masalah yang kompleks dan terurut, fokus dalam memperhatikan masalah utama, tekun meskipun menemui kesulitan, teliti dengan mempertimbangkan subjek dan keadaan. Dengan demikian dapat diartikan bahwa salah satu siswa dalam menyelesaikan masalah persamaan nilai mutlak linier satu variabel berpotensi memiliki kemampuan disposisi berpikrir kritis yang berkategori rendah.

Berdasarkan hasil penelitian ini peneliti menyarankan Guru lebih aktif lagi dalam kegiatan belajar mengajar sesuai dengan tuntunan Kurikulum 2013, melalui penerapan pembelajaran secara kontruktivisme untuk menumbukan disposisi berpikir kritis siswa dalam memecahkan masalah, terlebih dalam masalah matematika. Penelitian ini masih perlu banyak perbaikan dikarenakan subjek masih sedikit, selain itu referensi yang digunakan pun masih sangat terbatas dan peneliti masih belum berpengalaman dalam hal penelitian kualitatif dalam penelitian ini. 


\section{DAFTAR RUJUKAN}

Abrami, P. C., Bernard, R. M., Borokhovski, E., Wade, A., Surkes, M. A.,Tamim, R., \& Zhang, D. (2008). Instructional Interventions Affecting Critical Thinking Skills and Dispositions: A Stage 1 Meta-Analysis. Review of Educational Research, 78(4), 11021134. doi: 10.3102/0034654308326084.

Alghadari, F. (2013, Februari). Pembelajaran Berbasis Masalah untuk Meningkatkan Kemampuan dan Disposisi Berpikir Kritis Matematik Siswa SMA. Jurnal Universitas Pendidikan Indonesia. ISNN 1412-565 X.

As'ari, A. R., Mahmudi, A., \& Nuerlaelah, E. (2017). Our Prospective Mathematic Teachers Are Not Critical Thinkers Yet. Journal on Mathematics Education, 8(2), 145-156. doi: 10.22342/jme.8.2.3961.145-156.

As'ari, dkk. (2019). Ragam Soal Matematis untuk Mengembangkan Disposisi Berpikir Kritis. Edisi 1. Malang: Universitas Negeri Malang.

Astawa, I. W. P., Budayasa, I. K., \& Juniati, D. (2018). The Process of Student Cognition in Constructing Mathematical Conjecture. Journal on Mathematics Education, 9(1), 1526. doi: 10.22342/jme.9.1.4278.15-26.

Bakir, S. (2015). Critical Thinking Dispositions of Pre-Service Teachers. Educationa Research and Riview, 10(2), 225-233. doi: 10.5897/EER2014.2021.

Connie, S.L. (2006). Approaches to Evaluate Critical Thinking Dispositions. APERA Conference, (23-30 November 2006, Hong Kong).

Bestari, E. (2018). Deskripsi Disposisi Berpikir Kritis Matematis Siswa Kelas VII SMPN 20 Bandarlampung Dalam Pembelajaran Socrates Saintifik (Skripsi, Universitas Lampung Bandarlampung).

Damayanti, I., Yunarti, T., Widyastuti. (2015). Deskripsi Disposisi Berpikir Kritis Matematis Siswa Dalam Pembelajaran Socrates Kontekstual. Jurnal Hasil Riset jpmatematikadd, 15(2),40-52.

Facione, P. A.,dkk. (1995). The Disposition Toward Critical Thinking. Jurnal General Education, 44(1), 1-25. www.jstor.org/stable/27797240.

Fuat. (2014). Pengembangan Buku Ajar Geometri Yang Membangun Kemampuan Membuktikan (Tesis, Universitas Negeri Malang).

Gelerstein, dkk. (2016). Designing and Implementing a Test for Measuring Critical Thinking in Primary School. Jurnal Thinking Skills and Creativity, 20, 40-49. doi: 10.1016/j.tsc.2016.02.002.

Herlina, E. (2013). Meningkatkan Disposisi Berpikir Kreatif Matematis Melalui Pendekatan APOS. Infinity Journal, 2(2), 169-182. doi: 10.22460/infinity.v2i2.p169-182

Hunaepi, dkk. (2018). Validitas Perangkat Pembelajaran Model Inkuiri Terintegrasi Kearifan Lokal Untuk Melatih Keterampilan Berpikir Kritis Dan Disposisi Berpikir Kritis Mahasiswa. JUDIKA (JURNAL PENDIDIKAN UNSIKA), 6(2), 47-58.

Indrawatiningsih, dkk. (2019). The Ability of High School Students' Critical Thinking in Solving Trigonometric Problems. IOP Conference Series: Earth and Environmental Science 243(2019)012050. doi:10.1088/1755-1315/243/1/012050.

Insight Assessment. (2017, Agustus). California Critical Thinking Dispositions Inventory: A Measure of the Critical Thinking Mindset User, User Manual and Resource Guide.San Jose, CA: California Academic Press. www.insightassessment.com/article/californiacritical-thinking-disposition-inventory-cctdi-2.

Kurniati, D; Purwanto; As'ari, A.R.; \& Dwiyana. (2018). Exploring the Mental Structure and Mechanism: How the Style of Truth-Seekers in Mathematical Problem Solving. 
Journal of Mathematics Education, 9(2), 311-326. www.researchgate.net/publication/328280789.

Kurniati, D., dkk. (2019). Development and Validity of Problems WITH Contradictory Information and no Specified Universal Set to Measure the Truth-Seeking of PreService Mathematics Teachers. TEM Jurnal, 8(2), 545-553. doi:10.18421/TEM82-30.

Lai, E. R. (2011). Critical Thinking: "A Literature Review Research Report, (June). www.sciepub.com/reference/230104.

Lestari, K. E., \& Yudhanegara, M. R. (2017). Penelitian Pendidikan Matematika. Bandung: PT Refika Aditama Bandung.

Mahmudi, A. (2011). Problem Solving untuk Menilai Hasil Belajar Matematika. Seminar Nasional Matematika dan Pendidikan Matematika Universitas Negeri Yogyakarta, 20, (ISBN: 978-979-16353-6-3).

Moore, K. (2010). The Three-Part Harmony of Adult Learning, Critical Thinking, and Decision-Making. Journal of Adult Education, 39(1), 1-10.

Nugroho, P. B., Nusantara, T., As'ari, A. R., Sisworo, Hidayanto, E., \& Susiswo. (2018). Critical Thinking Disposition: Students Sceptic in Dealing with Ill-Logical Mathematics Problems. International Journal of Instruction, 11(3), 635-648. doi: 10.12973/iji.2018.11343a.

Sholihah, D., Shanti, W. (2017). Diposisi Berpikir Kritis Matematis Dalam Pembelajaran Menggunakan Metode Socrates. JKPM, 4(2), 2339-2444.

Wang, Sun, Huang, He, Hao, \& Zhang. (2017). Development And Validation Of Critical Thinking Disposition Inventory For Chinese Medical College Students (CTDI-M). Working Paper, (Cornell University). doi: 10.1186/s12909-019-1593-z.

Yu, Y., Zeng, T., \& Wang, C. (2009). Characteristics of Contradictory Information and Its Presentation. In 2009 International Conference on Signal Processing Systems (ICSPS) (pp. 394-397). doi: 10.1109/ICSPS.2009.123. 